\title{
Impact of fermented whey addition on resulting sensory characteristics and consumer preference of ripened cheeses
}

\author{
Saris Ulises Ramos-Gabriel', José Andrés Herrera-Corredor², José Guadalupe Gamboa-Alvarado', \\ Emmanuel de Jesús Ramírez-Rivera ${ }^{2 *}$ \\ ${ }^{1}$ Universidad del Mar Campus, Campus Puerto Escondido, Oaxaca 71980, México, ${ }^{2}$ Colegio de Postgraduados Campus Córdoba, Km. 348 \\ Carretera Federal Córdoba-Veracruz, 94500, Córdoba, Veracruz, México
}

\section{A B S T R A C T}

\begin{abstract}
The objective of this research was to evaluate the impact of fermented whey on the sensory characteristics of ripened cheeses and consumer preference. Ripened cheeses from 24, 25, 26, 27 and 28 months were characterized. The sensory techniques used were: Quantitative Descriptive Analysis ${ }^{\circledR}$, Temporal Dominance of Sensations and External Preference Mapping. The results showed that the ripened cheeses of 24 to 27 months they were characterized by white color, acidified milk smell, fat aroma and acidified cream smell. The cheese of 28 months of ripened was perceived as fermented milk smell, cow smell and fat smell. The dominant attributes were fat aroma, bitter aftertaste, acid aftertaste and salty. Consumers preferred cheeses from 26 and 27 months of ripening. These results demonstrate the potential use of fermented whey as an alternative to produce ripened cheeses with sensory characteristics and their relation to consumer preference.
\end{abstract}

Keywords: External preference mapping; Quantitative descriptive analysis; Temporal dominance of sensations

\section{INTRODUCTION}

Artisanal cheeses are part of the cultural heritage that give identity to the place where they are made (Villegas et al., 2009). They are also a source of proteins, lipids, vitamins and minerals (Moreno-Rojas et al., 2010). In Europe, the per capita consumption of ripened cheeses is $20 \mathrm{~kg}$ per year and in Latin America its $2.1 \mathrm{~kg}$ per year (Cervantes-Escoto \& Villegas, 2014). In 2016, Cheese production in Mexico was 751, 370 ton with a value of 1, 495 million dollars (SIAP, 2017). Whey is one of the by-products derived from the production of cheeses which is discarded to the rivers causing a negative impact (Rebollar-Rebollar et al., 2011; Leizaola, 2011) to the environment. The use of fermented whey with cultures (Lactococcus lactis and Lactococcus cremoris) can contribute to produce ripened cheeses at a lower cost and sensory characteristics appealing to consumers (Cuffia et al., 2017). However, in order to understand the impact of using fermented whey in the manufacture of ripened cheeses, is it required to study the following aspects: 1) sensory characterization; 2) sensory behavior in real time of consumption and 3) consumer preference. The aforementioned aspects can be analyzed through the combination of sensometric techniques such as Quantitative Descriptive Analysis $\left(\mathrm{QDA}^{\mathbb{B}}\right)$, Temporal Dominance of Sensations (TDS) and External Preference Mapping (PREFMAP) can generate information about the aforementioned aspects (Stone \& Sidel, 2004; Pineau et al., 2009; Ramírez-Rivera et al., 2018). Currently there is no evidence of sensometric investigations of ripened cheeses made with fermented whey. The objective of this research was to evaluate the impact of fermented whey in the sensory characteristics of ripened cheeses and the consumer preference.

\footnotetext{
${ }^{*}$ Corresponding author:

Emmanuel de Jesús Ramírez-Rivera, Colegio de Postgraduados Campus Córdoba, Km. 348 Carretera Federal Córdoba-9 Veracruz, 94500 , Córdoba, Veracruz, México. E-mail: ejramirezrivera@itszongolica.edu.mx
}

Received: 01 March 2019;

Accepted: 30 May 2019 


\section{MATERIALS AND METHODS}

\section{Obtaining and processing fermented whey}

The whey was obtained from the preparation of a fresh pasteurized cheese at the Laboratorio de Tecnologia de Productos Pecuarios (Technology of Livestock Products Laboratory) of Universidad del Mar, Campus Puerto Escondido (Gamboa-Alvarado et al.,2012). Prior fermentation, whey was stirred to obtain a homogeneous batch. The lactic fermentation was carried out using Lactococcus lactis and Lactococcus cremoris (Alcatraz S.A. de C.V. de Mexico) for a period of four days at of $27 \pm 2^{\circ} \mathrm{C}$ and relative humidity of $85 \pm 5 \%$ (Gamboa-Alvarado et al., 2012). After the fermentation time, the supernatant was filtered using a colander and used for the cheese treatment preparation. Acidity of fermented whey was determined according to AOAC 947.05 methodology (AOAC, 1995). Fermented whey used for this study had an acidity of $69^{\circ}$ Dornic (Gatti et al., 2008).

\section{Preparation of ripened cheeses}

Fresh milk obtained from Campo experimental de la Universidad del Mar Campus Puerto Escondico Milk was pasteurized (APIMAT model 304, Mexico) to $63^{\circ} \mathrm{C}$ per $30 \mathrm{~min}$. Then, $4 \mathrm{~g}$ of $\mathrm{CaCl}_{2}$ (diluted in $5 \mathrm{~mL}$ of water) for each 20 liters were added to milk. Subsequently $12 \mathrm{~mL}$ of commercial rennet (curdling force 1:10,000 or $110 \mathrm{IMCU} \mathrm{mL}^{-1}$, Cuamex Industry, Mexico) were added. Then, the fermented whey was added. Once the coagulation was complete, the curds were cut at a temperature of $50^{\circ} \mathrm{C}$ and allowed to rest for $30 \mathrm{~min}$. Then, the curds were drained using different pieces of cotton fabric for each of the containers. Drained curds were placed in molds of Polyvinil chloride (PVC) of $80 \mathrm{~mm}$ in diameter and $95 \mathrm{~mm}$ in height (to obtain samples of $300 \mathrm{~g}$ ) to press them ( $2 \mathrm{~kg}$ force per $1 \mathrm{~kg}$ cheese) for $24 \mathrm{~h}$. Subsequently, the cheeses were submerged in a brine $20 \%$ (w/v) (Refined salt, salt la fina ${ }^{\circledR}$ of Mexico) for 7 to $8 \mathrm{~h}$. Finally, the cheeses were stored in a fermentation chamber at a temperature of $23 \pm 2^{\circ} \mathrm{C}$ and with relative humidity of $65 \pm 5 \%$. Ripening times were 24 (QT1), 25 (QT2), 26 (QT3), 27 (QT4) y 28 (QT5) months (Mazzeo-Meneses et al., 2009). Criteria for selection of ripening times were: 1) cheeses showed a greater diversity of sensory attributes at these times (Romani et al., 2002) and 2) ripening times are similar to those for commercial Parmigiano-Reggiano cheese (Sforza et al., 2012).

\section{Preparation of samples for sensory analysis}

Sample size used for this study was $20 \mathrm{~g}$ (pieces of 1.5-cm diameter and 3-cm thickness) (Ramírez-Rivera et al., 2017a). A three randomly-selected digits were used for coding samples (Ramírez-Rivera et al., 2017a). Judges were provided with water and a baked cookie (Sanissimo ${ }^{\circledR}$ of Mexico) as a palate cleanse to eliminate the possible left over residues from the previous sample.

\section{$\mathrm{QDA}^{\circ}$ : Panel and sensory procedure}

The panel consisted of 10 subjects ( 5 women and 5 men with ages between 25 to 54 years) from the Universidad del Mar Campus Puerto Escondido. The judges were selected according to ISO 8586-1 (1993) and ISO 11035 (1994). In the first stage it was determined their availability, motivation and non-aversion of each subject towards ripened cheeses (ISO 8586-1, 1993). In the second stage, tests of basic flavors, recognition of aromas (ISO 5496, 2005), triangular (ISO 4120, 2004a) and duo-trio tests (ISO 1039, 2004b) were conducted. The results of these tests were processed using the Sequential Analysis technique (the parameters were $p=0.30, p 1=0.70, \alpha=0.10$ and $\beta=0.10)$ to select the judges (ISO 16820, 2004). The sensory profile was made using the QDA ${ }^{\circledR}$ technique in accordance with ISO 11035 (ISO, 1994) with some modifications. A scale of $9 \mathrm{~cm}$ was used because it is more sensitive than other scales (Ramirez et al., 2018). Sensory attributes evaluated were: white color (WHIT-C), fat smell (FAT-S), fermented milk smell (FERM-S), acidified milk smell (ACIM-S), acidified cream smell (ACCR-S), cow smell (COW-S), salty (SALT), sour (SOU), bitter (BITT), fat aroma (FAT-A), sour aftertaste (SOU-AF) y bitter aftertaste (BITT-AF). The sensory attributes were selected according to the procedure of arithmetic mean (ISO 11035, 1994). The definition and its operative mode of each attribute was determined (ISO $11035,1994)$ by consensus. Commercial type panela cheeses were used (Lala ${ }^{\circledR}$ and Alpura ${ }^{\circledR}$ of Mexico) as references for the evaluation of each sensory attribute (Rainey, 1986). A total of 15 tasting sessions were conducted in order to collect sensory data from cheese samples and to determine the panel performance. Each session lasted approximately $50 \mathrm{~min}$. The evaluation of the cheeses was sequential monadic based on an optimized experimental design (MacFie et al., 1989; Périnel \& Pagès, 2004).

\section{TDS: Panel and sensory procedure}

The panel for TDS consisted of 20 consumers (10 women and 10 men with ages between 13 to 55 years). Consumer screening criteria were: 1) Cheese consumption at least twice a week (Bemfeito et al., 2016); 2) no allergy to dairy products (Rodrigues et al., 2014); 3) good oral and general health (Rodrigues et al., 2016) and 4) results of the triangular tests (ISO 4120, 2004). Sequential Analysis technique $(\mathrm{p}=0.30, \mathrm{p} 1=0.70, \alpha=0.10$ and $\beta=0.10$ ) with triangular test results were used for consumer screening (ISO 16820, 2004c; Da Silva et al., 2014). Five training sessions (two hours per session) with the software SensoMaker were conducted with the selected consumers for them to understand the concept of dominant attribute (a dominant attribute that captures 
attention in a given time) and the product evaluation procedure (Pineau et al., 2009).

Consumers performed the TDS test as follows: 1) clicking on the "start" button 2) place $5 \mathrm{~g}$ of cheese in the mouth for a period of $2 \mathrm{~s}$ (delay time). 3) After the delay time and for a period of $20 \mathrm{~s}$, consumers used the mouse to select the dominant attribute during until the test ended. Each consumer was free to select any attribute several times (Pineau et al., 2009) during the evaluation time. The sensory attributes evaluated were: sour (SOU), bitter (BIT'T), fat aroma (Fat-A), sour aftertaste (SOU-AF) and bitter aftertaste (BIT'T-AF), these attributes were selected according to their probability value $(\mathrm{P} \leq 0.05)$ generated by the results of the QDA ${ }^{\circledR}$ panel. The order of the samples was randomized and served in a sequential monadic manner (MacFie et al., 1989). Each sample of cheese was presented in white plastic cups previously coded with three digits.

\section{Consumer study}

The study was conducted using a central location test with a total of 100 consumers who regularly consume ripened cheeses (50 women and 50 men with ages between 16 and 54 years old). Liking was evaluated using a nine-point hedonic scale $(1=\mathrm{I}$ dislike it extremely and $9=\mathrm{I}$ like it extremely). Sample size used was $20 \mathrm{~g}$ of each cheese. Samples were presented randomly to consumers to avoid presentation order error. Samples were coded using a three-digit code and presented in a sequential monadic way (Ramírez-Rivera et al., 2017b).

\section{Statistical analysis Quantitative descriptive analysis (ODA $\left.{ }^{\circledR}\right)$}

Panel performance was evaluated according to an ANOVA model with three factors and their interactions:

$\mathrm{Y}_{i k s}=\mu+a_{i}+\beta_{k}+\gamma_{s}+a \beta_{\mathrm{ik}}+\beta \gamma_{k s}+\alpha \gamma_{i s}+e_{i k s}$

Where $\mathrm{Y}_{i k s}$ represents the result of a judge $i$ for session $s$ in the product $k ; \mu$ is the general average; $a_{i}$ is the judge effect, $\beta_{k}$ is product effect; $\gamma_{s}$ is Session effect; $a \beta_{\mathrm{ik}}$ Product $\mathrm{x}$ Judge interaction; $\beta \gamma_{k s}$ Product $\mathrm{x}$ Session interaction; $a \gamma_{i s}$ Judge $\mathrm{x}$ Session interaction and $e_{i j k}$ is the term error of the model where $e_{i k s} \sim \mathrm{N}\left(\sim 0, \sigma^{2}\right)$. All tests of $F$ were obtained using the residual variance as the denominator (Husson et al., 2001). The sensory map was represented by Principal Component Analysis (PCA). The stability of the sensory map was determined by the technique confidence ellipses ( $90 \%$ and with 500 times) and the Hotelling $T^{2}$ test (Cadoret and Husson, 2013).

\section{TDS}

TDS curves were constructed according to Pineau et al. (2009). Each TDS curve included two lines indicating: 1) the "chance level" (rate of dominance occurring by chance on each attibute) and 2) "significance level" (the minimum value for considering the dominance rate as significant). The level of significance was calculated according to Pineau et al. (2009) using a confidence interval of a binomial proportion based on a normal approximation:

$$
P s=P_{0}+1.645 \sqrt{\frac{P_{o}\left(1-P_{0}\right)}{n}}
$$

Equation elements are: $P s=$ lowest significant proportion value $(\alpha=0.05)$ at any point in time for the TDS curve, $P_{0}=1 / p$, with $p$ being the number of attributes, and $n=$ number of subjects per replication. For calculations, $P_{0}$ was set to 0.17 , the minimum number of observation was $\mathrm{n}=5 /(0.17 \times(1-0.17))=36$. A number of 20 consumers had to perform two evaluations (replications) for each product (i.e. 40 trials). The number of evaluations carried out in the study met the minimum value of 30 as suggested by Pineau et al. (2012).

Two different ANOVA models were used sequentially. The first ANOVA model was to determine the performance of the TDS panel based on each evaluation time (Dinnella et al., 2013; Lepage et al., 2014):

$Y_{i k s}=\mu+a_{i}+\beta_{k}+\gamma_{s}+a \beta_{\mathrm{ik}}+\beta \gamma_{k s}+a \gamma_{i s}+e_{i k s}$

Where $Y_{i k s}$ represents the consumer's result $i$ for the attribute $s$ in the product $k ; \mu$ it is the general average; $a_{i}$ it is the consumer effect, $\beta$ it is product effect; $\gamma$, it is attribute effect; $a \beta_{\mathrm{ik}}$ is the Product x Consumer interaction; $\beta \gamma_{k s}$ is the Product $\mathrm{x}$ Attribute interaction; $a \gamma_{i s}$ is the Consumer $\mathrm{x}$ Attribute interaction and $e_{i j k}$ is the term error of the model with $e_{i k s} \sim \mathrm{N}\left(\sim 0, \sigma^{2}\right)$. The second model of ANOVA was used to determine the attributes that allowed to differentiate the cheeses according to the dominance rate $(\mathrm{Ng}$ et al., 2012):

$Y_{i k}=\mu+a_{i}+\beta_{k}+a \beta_{\mathrm{ik}}+e_{i k s}$

Where $Y_{i k}$ represents the result of the product $k$ generated by the consumer $i ; \mu$ it is the general average; $a_{i}$ it is the consumer effect; $\beta_{k}$ is the product effect; $a \beta_{\mathrm{ik}}$ is the Product $\mathrm{x}$ Consumer interaction and $e_{i j k}$ is the term error of the model with $e_{i k, s} \sim \mathrm{N}\left(\sim 0, \sigma^{2}\right)$ (Husson et al., 2001). The maximum value of dominance rate $(V \max )$ and time to reach $V \max (T \max )$ were used for the interpretation of TDS results (Pineau et al., 2009). The Vmax values were used to generate the sensory map via PCA. The stability of the sensory map was determined by the technique confidence ellipses ( $90 \%$ and with 500 times) and the Hotelling $T^{2}$ test (Cadoret \& Husson, 2013). 


\section{External preference mapping}

The External Preference Mapping (PREFMAP) was conducted in two successive stages following RamírezRivera's et al. (2018) strategy: stage 1) consumer class definition through the technique Hierarchical Classification Ascending (HCA) Ward method. 2) correlation of consumer classes $(\mathrm{Y})$ against $\mathrm{QDA}^{\circledR}$ sensory profile and TDS $(\mathrm{X})$ using the following model:

Vector model: $Y_{i}=a+\beta_{1} \mathrm{X}_{1}+\mathrm{b}_{2} \mathrm{X}_{2}+\varepsilon$

Where X (data QDA $^{\circledR}$ and TDS profile) and Y (hedonic data grouped into classes) were the coordinates of the cheese in the first and second principal component and $Y i$ was the hedonic value assigned by a consumer class to each cheese. The $a$ y $\beta_{1}$ were the coefficients of the model and $\varepsilon$ was the error term of the model. The coefficient of determination $\left(R^{2}\right)$ was used to determine the fit between the hedonic data and the sensory profiles (Ramírez-Rivera et al., 2018).

Analysis of Variance and Confidence ellipses were performed using SensoMineR (Lê-Dien \& Husson, 2008) packages implemented in programming language $\mathrm{R}$ version 3.2.5 (R Core Team, 2016). The TDS curves were built using SensoMaker version 1.91 software (Pinheiro et al., 2013). The External Preference Mapping and $R^{2}$ tests were conducted with the XLSTAT software (version 2015.6.01; Addinsoft, Paris, France).

\section{RESULTS AND DISCUSSION}

\section{$\mathrm{QDA}^{\circ}$ : Panel performance and sensory profile}

The performance results of the $\mathrm{QDA}^{\circledR}$ panel are shown in Table 1. The product factor indicated that the panel was highly discriminating $(\mathrm{P} \leq 0.0001)$ in all evaluated attributes. However, discrepancies were found among the judges for the evaluation of all the attributes $(\mathrm{P} \leq 0.0001)$.
The session factor determined that the panel was repetitive in all attributes except for WHIT-C, ACCR-S, ACIM-S y FAT-A $(\mathrm{P} \leq 0.0001)$. The panel was consensual in the attribute BITT-F $(\mathrm{P}=0.11)$ when positioning cheeses on the intensity scale (Cheese $\mathrm{x}$ Judge Interaction). The Cheese $\mathrm{x}$ Session interaction indicated that the panel generated similar notes between sessions in the attributes COW-S $(\mathrm{P}=0.38)$, FERM-S ( $\mathrm{P}=0.30)$, SALT $(\mathrm{P}=0.28)$, SOU $(\mathrm{P}=0.41)$, BIT'T $(\mathrm{P}=0.31)$, SOU-AF $(\mathrm{P}=0.11)$ and BITT-AF $(\mathrm{P}=0.70)$. The Judge $\mathrm{x}$ Session interaction indicated that the judges used the intensity scale in a similar way between sessions for the COW-S $(\mathrm{P}=0.20)$, ACCR-S $(\mathrm{P}=0.26)$, FERM-S $(\mathrm{P}=0.41)$, ACIM-S $(\mathrm{P}=0.08)$, SOU $(\mathrm{P}=0.71)$, BITT $(\mathrm{P}=0.88)$ and SOU-AF $(P=0.40)$ attributes. These results indicated that the panel met the criteria of discrimination and repeatability considered of interest in the performance of a sensory panel (Lê-Dien \& Worch, 2015).

The confidence ellipses are shown in Fig.1a. Sensory panel perceived the cheeses as different (Hotelling $T^{2}, \mathrm{P}<0.05$ ). Cheeses QT1 and QT2 (24 and 25 months of maturation, respectively) were perceived with high intensities of SALT, SOU, SOU-AF and BITT (Fig. 1b). Also cheeses QT3 and QT4 (26 and 27 months of maturation, respectively) were characterized as WHIT-C, ACCR-S and BITT-AF (Fig. 1b). Finally, the QT5 cheese (28 months of maturation) it was perceived as FERM-S, COW-S, FAT-S and FAT-A. Results of this study were consistent with that reported by Oliveira et al. (2012), Deegan et al. (2013), Queiroga et al. (2013) and Ramírez-Rivera et al. (2017b) whom evaluated ripened cheeses inoculated with Lactobacillus and Lactococcus. They observed that these cheeses exhibited attributes such as white color, sour smell, smell of fat, cow smell and grease aroma. The SALT attribute could be due to the release of peptides by proteolysis that can cause a low perception of humidity and increased perception of salting (Lima et al., 2008). The COW-S attribute is mainly related to the type of grass used as a livestock feed source

Table 1: Probability values $(P)$ of the performance of the $Q D A^{\circledR}$ panel

\begin{tabular}{|c|c|c|c|c|c|c|}
\hline Attribute & Product & Judge & Session & Product $\mathrm{x}$ Judge & Product x Session & Judge $\mathrm{x}$ Session \\
\hline WHIT-C & $<0.0001$ & $<0.0001$ & $<0.0001$ & $<0.0001$ & 0.00 & $<0.0001$ \\
\hline COW-S & $<0.0001$ & $<0.0001$ & 0.52 & $<0.0001$ & 0.38 & 0.20 \\
\hline FAT-O & $<0.0001$ & $<0.0001$ & 0.06 & $<0.0001$ & 0.00 & 0.02 \\
\hline ACCR-S & $<0.0001$ & $<0.0001$ & $<0.0001$ & $<0.0001$ & 0.00 & 0.26 \\
\hline FERM-S & $<0.0001$ & $<0.0001$ & 0.82 & 0.03 & 0.30 & 0.41 \\
\hline ACIM-S & $<0.0001$ & $<0.0001$ & $<0.0001$ & $<0.0001$ & 0.00 & 0.08 \\
\hline SALT & $<0.0001$ & $<0.0001$ & 0.69 & 0.02 & 0.28 & $<0.0001$ \\
\hline SOU & $<0.0001$ & $<0.0001$ & 0.29 & 0.03 & 0.41 & 0.71 \\
\hline BITT & $<0.0001$ & $<0.0001$ & 0.04 & $<0.0001$ & 0.31 & 0.88 \\
\hline FAT-A & $<0.0001$ & $<0.0001$ & $<0.0001$ & $<0.0001$ & 0.00 & $<0.0001$ \\
\hline SOU-AF & $<0.0001$ & $<0.0001$ & 0.30 & 0.04 & 0.11 & 0.40 \\
\hline BITT-AF & $<0.0001$ & $<0.0001$ & 0.05 & 0.11 & 0.70 & $<0.0001$ \\
\hline
\end{tabular}

WHIT-C=white color; FAT-S=smell of fat; FERM-S=smell of fermented milk; ACIM-S=smell of acidified milk; ACCR-S=smell of acidified cream; COW-S=smell of cow; SALT=salty; SOU=sour; BITT=bitter; FAT-A=fat aroma; SOU-AF=sour aftertaste; BITT-AF=bitter aftertaste. 
(O'Callaghan et al., 2017). The FERM-O and FERM-S attributes could be generated by the fermentation of lactose and compounds derived from lipolysis as the 3-methylbutanoic acid (Ramírez-Rivera et al., 2018).

\section{TDS: Panel performance and sensory profile}

The performance results of the TDS panel are shown in Table 2. Where, the product factor showed that the panel discriminated the cheeses in the time period T17 to T20 $(\mathrm{P} \leq 0.0001)$. The consumer factor indicated agreements $(\mathrm{P} \geq 0.05)$ between the evaluators for the determination of the dominance of the attributes during the cheese evaluation time. The attribute factor showed that each

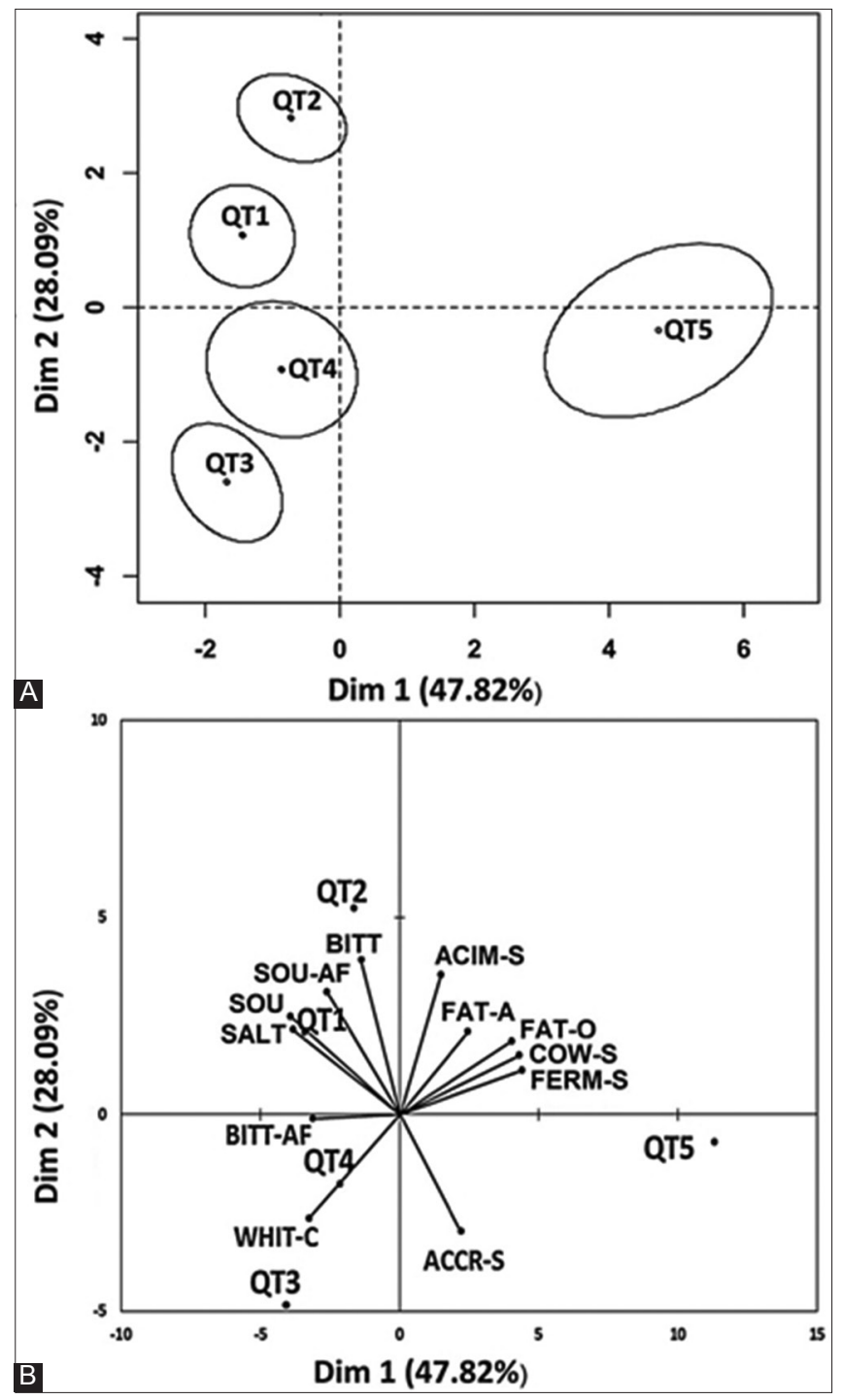

Fig 1. (A) Ellipses of Confidence ( $90 \%$ and with 500 times) evaluated with the Hotelling $T^{2}$ test and (B) Principal Components Analysis of the $\mathrm{QDA}^{\circledR}$ panel. QT1 = 24 months; QT2 $=25$ months; QT3 $=26$ months; QT4 =27 months; QT5 = 28 months. WHIT-C = white color; FAT-S $=$ smell of fat; FERM-S $=$ smell of fermented milk; ACIM-S $=$ smell of acidified milk; ACCR-S $=$ smell of acidified cream; COW-S = smell of cow; SALT = Salty; SOU = sour; BITT = bitter; FAT-A = fat aroma; SOU-AF = sour aftertaste; BITT-AF = bitter aftertaste. evaluated attribute allowed to differentiate the cheeses in the periods from T1 to T6 and later from T12 to T20. The Product $x$ Consumer interaction were similar $(\mathrm{P} \geq 0.05)$ for the dominance assignments of each cheese evaluated. The Product $\mathrm{x}$ Attributes interaction indicated that different attributes characterized the cheeses in the periods: T1 to T5 and T9 to T20. The Consumer x Attributes Interaction indicated that consumers used attributes differently from T2 to T20. This may be due to differences in the chewing and salivation of each consumer (Foster et al., 2011; Ma et al. 2016). The aforementioned results indicate that the TDS panel was discriminant and consensual (Product $\mathrm{x}$ Consumer Interaction) as indicated by Lepage et al., (2014).

Table 3 shows the results of the two-way ANOVA. Results observed indicated that all the attributes considered in the TDS list allowed to differentiate the cheeses. However, the Consumer factor and the Product x Consumer interaction showed that the perception of attributes in the course of time (T1 to T20) differed among consumers. In Figures 2 and 3 and $4 a$ the TDS curves per cheese analyzed are shown. It is observed that the attributes with greater dominance (SALT, FAT-A, BITT-AF and SOU-AF) were perceived in the periods from 5 to $6 \mathrm{~s}$ and 8 to $20 \mathrm{~s}$. These attributes were also reported by Ramírez-Rivera et al. (2017b) as characteristic of ripened cheeses. The attributes SALT and GRAS-A were potentiated due to a

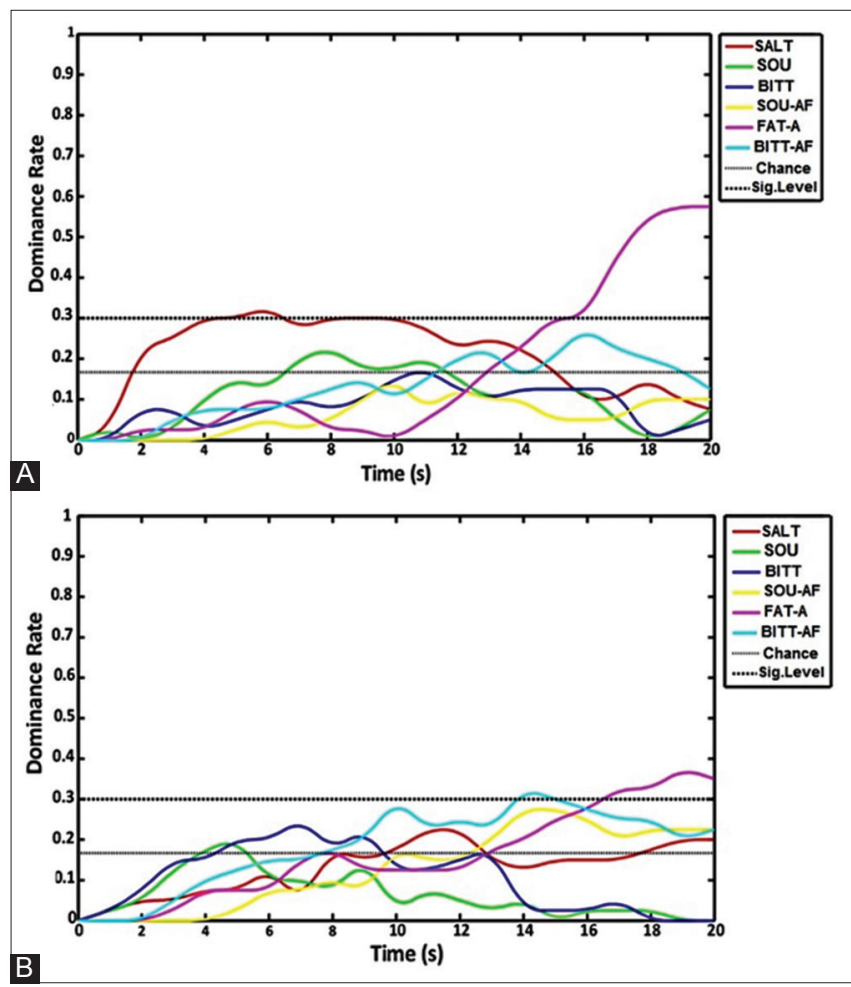

Fig 2. Curves TDS (40 evaluations): (A) QT1 $=24$ months of maturation and (B) QT2 $=25$ months of maturation; Chance $=0.17$ and Sig. Level $=0.3$. SALT = salty; SOU = sour; BITT = bitter; FAT-A = fat aroma; SOU-AF = sour aftertaste; BITT-AF = bitter aftertaste. 
Ramos-Gabriel, et al.

Table 2: Probability values $(P)$ for determining the performance of the TDS panel

\begin{tabular}{|c|c|c|c|c|c|c|}
\hline Time & Product & Consumer & Attributes & Product $\mathrm{x}$ Consumer & Product x Attributes & Consumer x Attributes \\
\hline T1 & 0.11 & 0.05 & 0.01 & 0.71 & 0.02 & 0.08 \\
\hline T2 & 0.34 & 0.08 & $<0.0001$ & 0.94 & 0.02 & 0.01 \\
\hline T3 & 0.45 & 0.11 & $<0.0001$ & 0.99 & 0.02 & $<0.0001$ \\
\hline T4 & 0.89 & 0.11 & $<0.0001$ & 1.00 & $<0.0001$ & $<0.0001$ \\
\hline T5 & 0.46 & 0.74 & $<0.0001$ & 1.00 & 0.02 & $<0.0001$ \\
\hline T6 & 0.76 & 0.93 & 0.02 & 1.00 & 0.20 & $<0.0001$ \\
\hline T7 & 0.30 & 0.96 & 0.06 & 1.00 & 0.21 & $<0.0001$ \\
\hline T8 & 0.57 & 1.00 & 0.20 & 1.00 & 0.16 & $<0.0001$ \\
\hline T9 & 0.25 & 1.00 & 0.17 & 1.00 & 0.01 & $<0.0001$ \\
\hline T10 & 0.47 & 1.00 & 0.24 & 1.00 & $<0.0001$ & $<0.0001$ \\
\hline T11 & 0.79 & 1.00 & 0.31 & 1.00 & 0.01 & $<0.0001$ \\
\hline T12 & 0.56 & 1.00 & 0.02 & 1.00 & $<0.0001$ & $<0.0001$ \\
\hline T13 & 0.65 & 1.00 & 0.01 & 1.00 & 0.02 & $<0.0001$ \\
\hline T14 & 0.17 & 1.00 & $<0.0001$ & 1.00 & $<0.0001$ & $<0.0001$ \\
\hline T15 & 0.41 & 1.00 & $<0.0001$ & 1.00 & $<0.0001$ & $<0.0001$ \\
\hline T16 & 0.41 & 1.00 & $<0.0001$ & 1.00 & $<0.0001$ & $<0.0001$ \\
\hline T17 & $<0.0001$ & 1.00 & $<0.0001$ & 1.00 & $<0.0001$ & $<0.0001$ \\
\hline T18 & $<0.0001$ & 1.00 & $<0.0001$ & 1.00 & $<0.0001$ & $<0.0001$ \\
\hline T19 & $<0.0001$ & 1.00 & $<0.0001$ & 1.00 & $<0.0001$ & $<0.0001$ \\
\hline T20 & $<0.0001$ & 1.00 & $<0.0001$ & 1.00 & $<0.0001$ & $<0.0001$ \\
\hline
\end{tabular}

T1-T20=It is the 20s that the TDS test lasts

Table 3: Probability values $(P)$ to determine the attributes that allow to differentiate the cheeses according to the TDS test

\begin{tabular}{lccc}
\hline Attribute & Product & Consumer & Product $x$ Consumer \\
\hline SALTY & $<0.0001$ & $<0.0001$ & $<0.0001$ \\
SOU & $<0.0001$ & $<0.0001$ & $<0.0001$ \\
BITTER & 0.01 & $<0.0001$ & $<0.0001$ \\
FAT-A & $<0.0001$ & $<0.0001$ & $<0.0001$ \\
SOU-AF & $<0.0001$ & $<0.0001$ & $<0.0001$ \\
BITTER-AF & $<0.0001$ & $<0.0001$ & $<0.0001$ \\
\hline
\end{tabular}

SALT=salty; SOU=sour; BITT=bitter; FAT-A=fat aroma; SOU-AF=sour aftertaste; BITT-AF=bitter aftertaste

loss of moisture and lipolysis reactions that occurred during maturation (Deegan et al., 2013; Gambaro et al., 2017). The TDS curves of QT1 cheese ( 24 months of maturation) were characterized mainly by the dominance of the attributes SALT $(\operatorname{Vmax}=0.32$ or $32 \%$ of consumers detected this attribute as dominant) and FAT-A (Vmax $=0.58$ or $58 \%$ of consumers detected this attribute as dominant), which obtained these values after evaluating them at $T \max =5.8$ and Tmax $=19.7 \mathrm{~s}$, respectively (Fig. 2a). This result agrees with that reported by Deegan et al. (2013) and Saint-Eve et al. (2015) whom reported the Fat and Salaty attributes as dominant in matured cheeses. The QT2 cheese (25 months of maturation) is observed that the attribute BITTAF reaches its value $\mathrm{Vmax}=0.36(36 \%$ of consumers detected this attribute as dominant) at $14.5 \mathrm{~s}$. After 17 to $20 \mathrm{~s}$ the attribute predominated FAT-A ( $\operatorname{mmax}=0.37$ and $T \max =19.2 \mathrm{~s}$ ) (Fig. $2 \mathrm{~b}$ ). The values of $\mathrm{Vmax}$ and Tmax of the cheeses QT2 demonstrated the dominance of the bitter and fat attributes. This could be due to the presence of ethanoic acid derived from the fermentation of lactic acid and the advanced state of lipolysis in cheeses

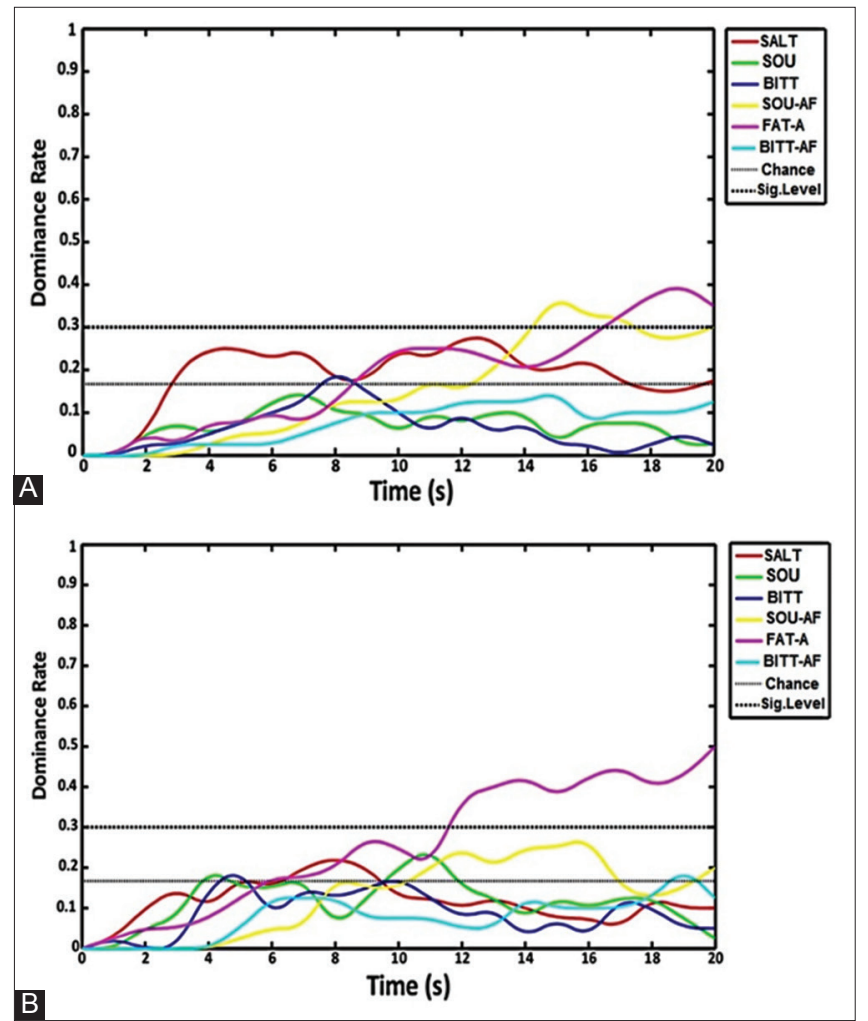

Fig 3. Curves TDS (40 evaluations): (A) QT3 $=26$ months of maturation and (B) QT4 = 27 months of maturation; Chance $=0.17$ and Sig. Level = 0.3. SALT = salty; SOU = sour; BITT = bitter; FAT-A = fat aroma; SOU-AF = sour aftertaste; BITT-AF = bitter aftertaste.

(Badui-Dergal, 2014; Witt \& Stokes, 2015). In the case of cheese QT3 (26 months of maturation), the first dominant attribute perceived was SOU-AF, who obtained 
a $V \max =0.36(36 \%$ of consumers detected this attribute as dominant) at $15.2 \mathrm{~s}$ (Tmax) (Fig. 3a). This result may be related to the high production of lactic acid (Teubner et al., 2009). While the attribute FAT-A was perceived as dominant by $39 \%$ of consumers $(V \max =0.39)$ from the second $17 \mathrm{~s}$ and reaching its $\mathrm{Vmax}$ at $18.8 \mathrm{~s}$. The FAT-A attribute was dominant due to the presence of fatty acids generated by the effect of ripening. According to the TDS curves shown in Figs. $3 \mathrm{~b}$ and $4 \mathrm{a}$, the aforementioned attribute was dominant from 11 to $20 \mathrm{~s}(\mathrm{~V} \max =0.50$ and Tmax $=20 \mathrm{~s})$ in cheese QT4 (27 months of maturation) and from 8 to $20 \mathrm{~s}(V \max =0.62$ and $T \max =19.2 \mathrm{~s})$ in the cheese QT5 (28 months of maturation). The dominance of the FAT-A attribute may be the result of the interaction between the whey, the fermentative lactic probiotics used and the ripening time ( $\geq 26$ months) that contributed to the degradation of fat particles for the release of short chain free fatty acids such as acetate and butyrate (Deegan et al., 2013; Queiroga et al., 2013; Gambaro et al., 2017). The PCA generated with the average Vmax data is shown in Fig. 4b. In which, it is observed that cheese QT1 was perceived with greater intensity in the SALT attribute. Cheese QT2 was characterized by having high intensity of BITT and BITT-AF attributes. Cheeses QT3 and QT4 were related to the attribute SOU-AF while cheese QT5 was perceived as SOU and FAT-A. The confidence ellipses (Fig. 4c) with data from the TDS test demonstrated that: 1) cheese QT1 was perceived as different from the rest of the cheeses evaluated (Hotteling $T^{2}<0.05$ ); 2) cheeses QT2 and QT5 were significantly different between them (Hotteling $T^{2}<0.05$ ) and 3) the overlap of the confidence ellipses showed a progressive order as the maturation time of the cheeses increases (QT2- QT3-QT4 and subsequently QT3-QT4-QT5).

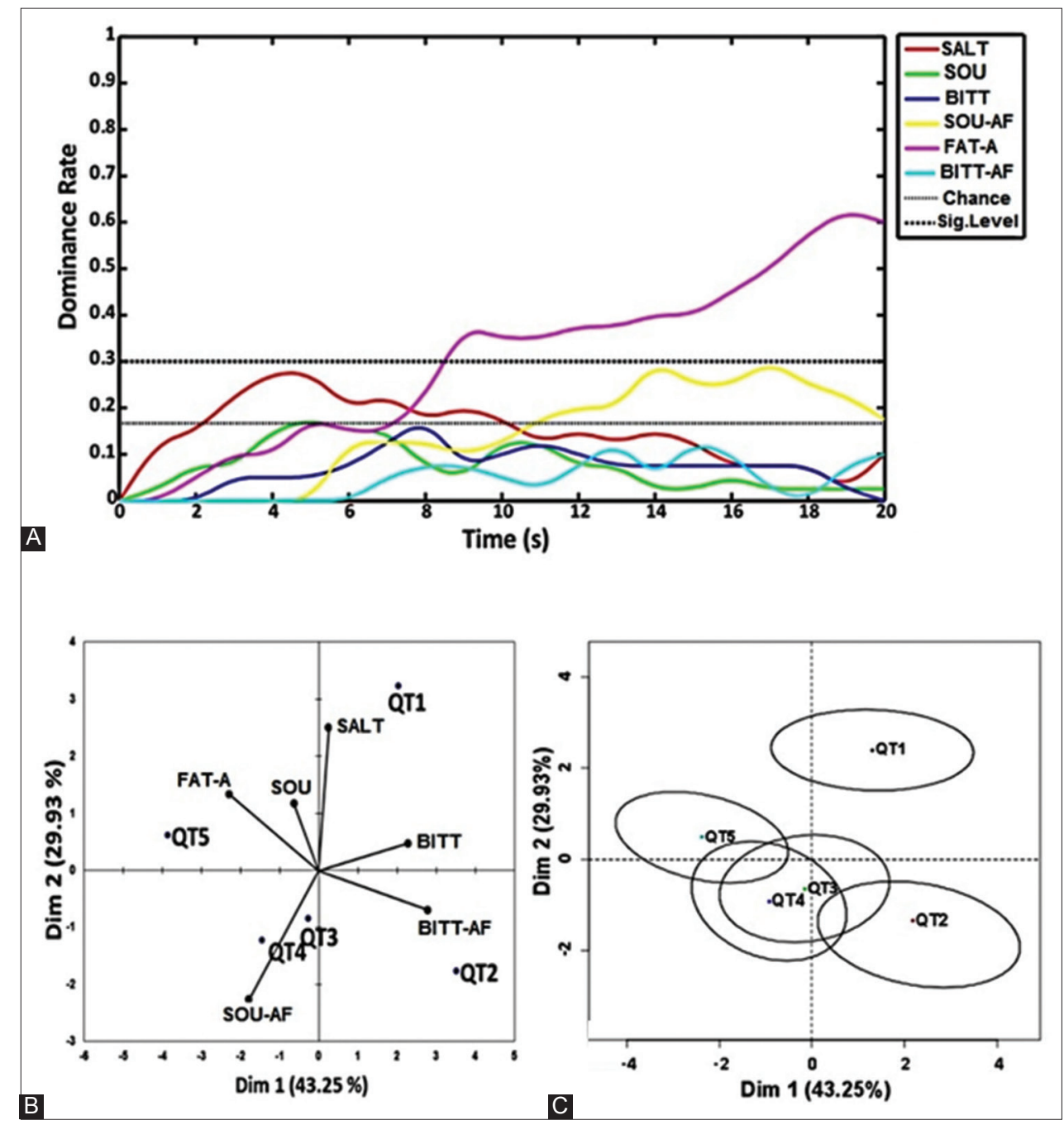

Fig 4. (A) Curves TDS (40 evaluations) of cheese QT5 = 28 months of maturation; Chance $=0.17$ and Sig. Level $=0.3$; (B) Principal Component Analysis and (C) Ellipses of Confidence ( $90 \%$ and with 500 times) generated with the values of maximum dominance rate (Vmax). SALT = salty; SOU = sour; BITT = bitter; FAT-A = fat aroma; SOU-AF = sour aftertaste; BITT-AF = bitter aftertaste. QT1 = 24 months; QT2 = 25 months; QT3 = 26 months; QT4 =27 months; QT5 = 28 months. 


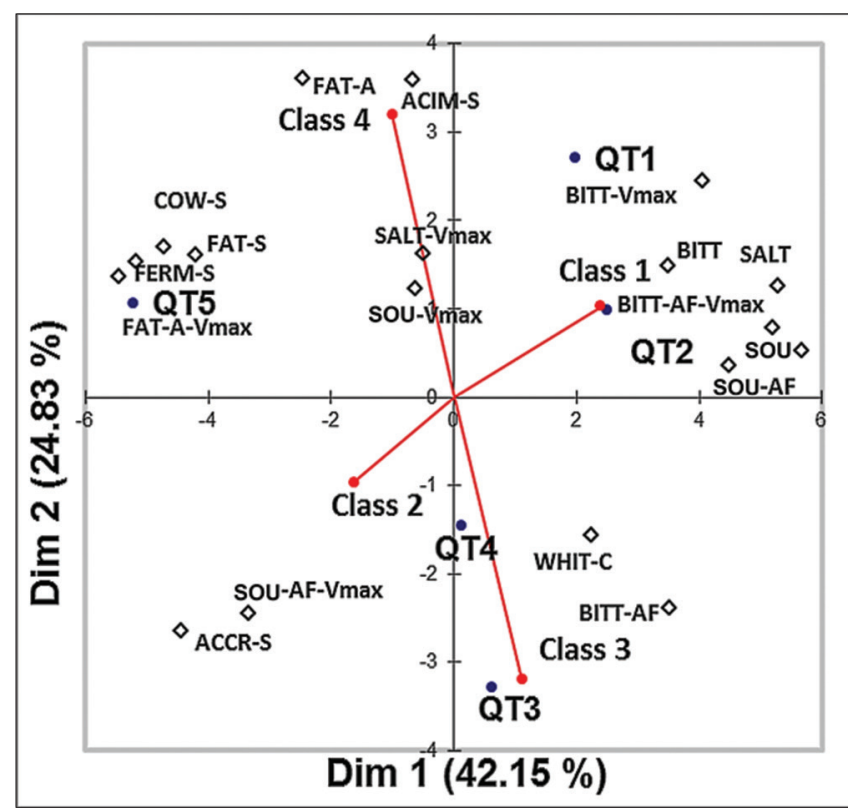

Fig 5. External Preference Mapping vector model ( $n=100$ consumers) with data QDA $^{\circledast}$ ( $n=10$ trained judges) and TDS ( $n=20$ consumers). WHIT-C $=$ white color; FAT-S $=$ smell of fat; FERM-S = smell of fermented milk; ACIM-S = smell of acidified milk; ACCR-S = smell of acidified cream; COW-S = smell of cow; SALT = salty; SOU = sour; BITT = bitter; FAT-A = fat aroma; SOU-AF = sour aftertaste; BITT-AF = bitter aftertaste. Vmax is the average dominance of the attribute. Class 1 ( $n=36$ consumers), Class 2 ( $n=42$ consumers), Class 3 ( $n=10$ consumers) and Class 4 ( $n=12$ consumers). QT1 $=24$ months; QT2 $=25$ months; $\mathrm{QT} 3=$ 26 months; QT4 =27 months; QT5 = 28 months.

\section{External preference mapping}

Cheeses QT1, QT2 and QT4 obtained scores of 5.8, 6 and 5.8 respectively and cheeses QT3 and QT5 were rated as 5.6 and 5.5 , respectively. The preference values positioned the cheeses in the region known as "I do not like or dislike" and "I like it slightly" (Cervantes et al., 2017) of the hedonic scale. Four consumer groups were formed as follows: Class 1 ( $n=36$ consumers), Class $2(n=42$ consumers), Class 3 ( $n=10$ consumers) and Class $4(n=12$ consumers). The PREFMAP model vector was able to explain the preference of consumer class $1\left(\mathrm{R}^{2}=0.87\right), 3$ $\left(\mathrm{R}^{2}=0.99\right)$ and $4\left(\mathrm{R}^{2}=0.95\right)$. Consumers of Class $1(36 \%$ of consumers) preferred cheeses (QT1 and QT2) with characteristics SOU, SOU-AF, BIT'T, SALT and with a greater dominance in BIT'T-Vmax and BITT-AF-Vmax (Fig. 5). Class 2 and 3 (52\% of consumers) preferred cheeses (QT3 and QT4) characterized as WITH-C, BIT'TAF, ACCR-S and SOU-AF-Vmax (Fig. 5). The results shown above agreed with the research of Ramírez-Rivera et al. (2018) whom reported that sensory attributes such as acidity and bitterness are related to consumers' preference for ripened cheeses. Class 4 (12\% of consumers) preferred QT5 cheese for being ACIM-S, COW-S, FERM-S, FAT-S and for having a longer time (8 to $20 \mathrm{~s}$ ) of dominance of FAT-A-Vmax (Fig. 5). This indicates that a high intensity and dominance of the attributes related to fat are related to the rejection of this type of cheese. The results of this research are useful for producers and industrial cheeses that require the use of fermented whey as an alternative for the production of this type of cheese. The use of whey can also minimize costs in the production of cheeses and the negative impact on the environment.

\section{CONCLUSIONS}

The results of this research indicated that ripened cheeses made with fermented whey are characterized by having dominant sensory attributes such as fat aroma, bitter aftertaste, acid aftertaste and salty. Hedonic data indicated that consumers preferred cheeses with 24 to 27 months of ripening. Attributes white color, smell of acidified cream, bitter aftertaste and acid aftertaste contributed to the explanation of consumer preference. The authors recommend carrying out texture and microscopy analyzes to explain the changes in the micro and macrostructure of the cheeses produced with fermented whey.

\section{Authors' contributions}

All authors contributed extensively in the planning, experimental design, analysis, interpretation of the results and writing of the article.

The authors declared no conflict of interest.

\section{REFERENCES}

AOAC. 1995. AOAC 947.05: Manual of Official Methods of Analysis. $15^{\text {th }}$ ed. Association of Official Analytical Chemists, Washington, USA.

Badui-Dergal, S. 2014. Química de los Alimentos. $5^{\text {th }}$ ed. Pearson Educación, México.

Bemfeito, R. M., J. F. Rodrigues, J. G. Silva and L. R. Abreu. 2016. Temporal dominance of sensations sensory profile and drivers of liking of artisanal Minas cheese produced in the region of Serra da Canastra, Brazil. J. Dairy Sci. 99(10): 7886-7897.

Cadoret, M. and F. Husson. 2013. Construction and evaluation of confidence ellipse applied at sensory data. Food Qual. Prefer. 28: $106-115$

Cervantes, E. F., D. A. L. Patiño, V. A. Cesín and S. M. V. González. 2017. Innovando los estudios de mercado de los quesos artesanales. El valor simbólico del queso de poro. Estud. Soc 27(49): 67-91.

Cervantes-Escoto, F. and G. A. Villegas. 2014. La leche y los quesos artesanales en México. Agric. Soc. Desarro. 11(2): 243-248.

Cuffia, F., G. George, P. Renzulli, J. Reinheimer, C. Meinardi and P. Burns. 2017. Technological challenges in the production of a probiotic pasta filata soft cheese. LWT-Food Sci. Technol. 81: 111-117.

Da Silva, T. L. T., V. R. de Souza, A. C. M. Pinheiro, C. A. Nunes and T. V. M. Freire. 2014. Equivalence salting and temporal dominance of sensations analysis for different sodium chloride substitutes in cream cheese. Int. J. Dairy Technol. 67: 31-38. 
Deegan, K. C., N. Heikintalo, T. Ritvanen, T. Putkonen, J. Rekonen, P. L. H. McSweeney, T. Alatossava and H. Tuorila. 2013. Effects of low-pressure homogenisation on the sensory and chemical properties of Emmental cheese. Innov. Food Sci. Emerg. Technol. 19: 104-114.

Dinnella, C., C. Masi, T. Naes and E. Monteleone. 2013. A new approach in TDS data analysis: A case study on sweetened coffee. Food Qual. Prefer. 30: 33-46.

Foster, K. D., J. M. V. Grigor, J. N. Cheong, M. J. Y. Yoo, J. E. Bronlund and M. P. Morgenstern. 2011. The role of oral processing in dynamic sensory perception. J. Food Sci. 76(2): 49-61.

Gámbaro, A., V. González, S. Jiménez, A. Arechavaleta, B. Irigaray, N. Callejas, M. Grompone and I. Vieitez. 2017. Chemical and sensory profiles of commercial goat cheeses. Int Dairy J. 69: $1-8$.

Gamboa-Alvarado, J. G., D. R. Almaraz and E. D. J. Ramírez-Rivera. 2012. Calidad fisicoquímica y sensorial de queso tipo Manchego durante la maduración. Rev. Cient. UDO Agríc. 12(4): 929-938.

Gatti, M., J. D. D. Lindner, A. De Lorentiis, B. Bottari, M. Santarelli, V. Bernini and E. Neviani. 2008. Dynamics of whole and lysed bacterial cells during Parmigiano-Reggiano cheese production and ripening. Appl. Environ. Microbiol. 74(19): 6161-6167.

Husson, F., S. Lê-Dien and J. Pagès. 2001. Which value can be granted to sensory profiles given by consumers? Methodology and results. Food Qual. Prefer. 12: 291-296.

ISO. 1993. Standard 8586-1: Sensory Analysis-General Guidance for the Selection, Training, and Monitoring of Assessors, Part 1-Selected Assessors. International Organization for Standardization, Geneva, Switzerland.

ISO. 1994. ISO 11035: Sensory Analysis Identification and Selection of Descriptors for Establishing a Sensory Profile by a Multidimensional Approach. International Organization for Standardization, Geneva, Switzerland.

ISO. 2004a. ISO 4120: Sensory Analysis-Methodology-Triangle Test. International Organization for Standardization, Geneva, Switzerland.

ISO. 2004b. ISO 10399: Sensory Analysis-Methodology-Duo-trio Test. International Organization for Standardization, Geneva, Switzerland.

ISO. 2004c. ISO 16820: Sensory Analysis-Methodology-Sequential Analysis. International Organization for Standardization, Geneva, Switzerland.

ISO. 2005. ISO 5496: Sensory Analysis-Methodology-Initiation and Training of Assessors in the Detection and Recognition of Odors. International Organization for Standardization, Geneva, Switzerland.

Lê-Dien, S. and F. Husson. 2008. Sensominer: A package for sensory data analysis. J. Sens. Stud. 23: 14-25.

Lê-Dien, S. and T. Worch. In: Chambers, M. J., T. Hothorn, D. TempleLang, H. Wickham, (Eds.), Quantitative Descriptive Approaches. Analyzing Sensory Data with R. $1^{\text {st }}$ ed. Taylor and Francis Group, CRC Press, Boca Raton.

Leizaola, C. F. 2011. Suero y requesón, productos poco valorados por los pastores vascos. Zainak. Cuad. Antropol. Etnogr. 34: 517-528.

Lepage, M., T. Neville, A. Rytz, P. Schlich, N. Martin and N. Pineau. 2014. Panel performance for temporal dominance of sensations. Food Qual. Pref. 38: 24-29.

Lima, C. D. L., M. M. Cerqueria, G. E. Ferreira, J. L. Faria, N. D. Lee, S. L. Carmo and A. C. Rosa. 2008. Microbiological, physicalchemical and sensory evaluation of a traditional Brazilian cheese during the ripening process. World J. Microbiol. Biotechnol. 24(11): 2389-2395
Ng, M., J. B. Lawlor, S. Chandra, C. Chaya, L. Hewson and J. Hort 2012. Using quantitative descriptive analysis and temporal dominance of sensations analysis as complementary methods for profiling commercial blackcurrant squashes. Food Qual. Prefer. 25(2): 121-134.

Ma, Q., N. Hamid, I. Oey, K. Kantono, F. Faridnia, M. Yoo and M. Farouk. 2016. Effect of chilled and freezing pre-treatments prior to pulsed electric field processing on volatile profile and sensory atributes of cooked lamb meats. Innov. Food Sci. Emerg. Technol. 37: 359-374.

MacFie, H. J., N. Bratchell, K. Greenhoff and L. V. Vallis. 1989. Designs to balance the effect of order of presentation and firstorder carry-over effects in hall tests. J. Sens. Stud. 4(2): 129148.

Mazzeo-Meneses, M. H., F. Díaz-Arango, L. E. Pérez-Barrera, L. León-Agatón, A. P. Castaño-Vélez and A. L. JaramilloGonzáles. 2009. Desarrollo de procesos productivos de quesos madurados en tres municipios del departamento de Caldas. Rev. Ing. Invest. 29(3): 42-47.

Moreno-Rojas, R., P. J. Sánchez-Segarra, F. Cámara-Martos and M. A. Amaro-López. 2010. Multivariate analysis techniques as tools for categorization of Southern Spanish cheeses: nutritional composition and mineral content. Eur. Food Res. Technol. 231(6): 841-851.

O'Callaghan, F. T., D. T. Mannion, D. Hennessy, S. McAuliffe, M. G. O'Sullivan, N. Leeuwendaal, T. P. Beresford, P. Dillon, K. N. Kilcawley, J. J. Sheehan, R. P. Ross and C. Stanton. 2017. Effect of pasture vesus indoor feeding systems on quality characteristics, nutritional composition, and sensory and volatile properties of full-fat Cheddar cheese. J. Dairy Sci. 100(8): 60536073.

Oliveira, G. M. E., E. F. Garcia, R. C. R. Queiroga and E. L. Souza. 2012. Technological, physicochemical and sensory characteristics of a Brazilian semi-hard goat cheese (coalho) with added probiotic lactic acid bacteria. Sci. Agric. 69(6): 370-379.

Périnel, E. and J. Pagès. 2004. Optimal nested cross-over designs in sensory analysis. Food Qual. Prefer. 15(5): 439-446.

Pineau, N., A. G. de Bouillé, M. Lepage, F. Lenfant, P. Schlich, N. Martin and A. Rytz. 2012. Temporal Dominance of Sensations: What is a good attribute list? Food Qual. Prefer. 26(2): 159-16.

Pineau, N., P. Schlich, S. Cordelle, C. Mathonnière, S. Issanchou, A. Imbert, M. Rogeaux, P. Etiévant and E. Köster. 2009. Temporal dominance of sensations: Construction of the TDS curves and comparison with time intensity. Food Qual. Prefer. 20(6) 450-455.

Pinheiro, A. C. M., C. A. Nunes and V. Vietoris. 2013. Senso maker: A tool for sensorial characterization of food products. Ciên. Agrotecnol. 37(3): 199-201.

Queiroga, E. R. C., S. B. Melo, G. A. M. Pereira, M. J. Monteiro, S. M. Teixeira, E. L. Souza, C. J. Dias Pereira and P. M. M. Estevez. 2013. Nutritional, textural and sensory properties of Coalho cheese made of goats, cows' milk and their mixture. LWT Food Sci. Technol. 50(2): 538-544.

Team, R. C. 2016. R: A Language and Environment for Statistical Computing. Vienna: R Foundation for Statistical Computing. Available from: https://www.r-project.org. [Last accessed on Retrieved on 2018 Jan 04].

Rainey, B. A. 1986. Importance of references standards in training panelists. J. Sens. Stud. 1(2): 149-154.

Ramírez-Rivera, E. J., P. Díaz-Rivera, L. G. Ramón-Canul, J. M. Juárez-Barrientos, J. Rodríguez-Miranda, E. Herman-Lara, W. Prinyawiwatkul and J. A. Herrera-Corredor. 2018. Comparison of performance and quantitative descriptive 
analysis sensory profiling and its relationship to consumer liking between the artisanal cheese producers panel and the descriptive trained panel. J. Dairy Sci. 101: 5851-5864.

Ramírez-Rivera, E. J., L. G. Ramón-Canul, P. Díaz-Rivera, J. M. Juárez-Barrientos, E. Herman-Lara, W. Prinyawiwatkul and J. A. Herrera-Corredor. 2017a. Sensory profiles of artisan goat cheeses as influenced by the cultural context and the type of panel. Int. J. Food Sci. Technol. 52(8): 1789-1800.

Ramírez-Rivera, E. J., J. M. Juárez-Barrientos, J. Rodríguez-Miranda, P. Díaz-Rivera, L. G. Ramón-Canul, J. A. Herrera-Corredor, M. I. Hernández-Serrano and E. Herman-Lara. 2017b. Typification of a goat fresh cheese of Mexico by path models. Turk. J. Vet. Anim. Sci. 41(2): 2013-220.

Ramírez-Rivera, E. J., P. Díaz-Rivera, L. G. Ramón-Canul, J. M. Juárez-Barrientos, J. Rodríguez-Miranda, E. Herman-Lara, W. Prinyawiwatkul and J. A. Herrera-Corredor. 2018. Comparison of performance and quantitative descriptive analysis sensory profiling and its relationship to consumer liking between the artisanal cheese producers panel and the descriptive trained panel. J. Dairy Sci. 101: 5851-5864.

Rebollar-Rebollar, S., J. Hernández-Martínez, F. J. Gonzales-Razo, A. García-Martínez, B. Albarrán-Portillo and R. Rojo-Rubio. 2011. Canales y márgenes de comercialización del queso añejo en Zacazonapan, México. Arch. Zootec. 60(232): 883-889.

Rodrigues, J. F., C. S. Gonçalves, R. C. Pereira, J. D. S. Carneiro and A. C. M. Pinheiro. 2014. Utilization of temporal dominance of sensations and time intensity methodology for development of low-sodium Mozzarella cheese using a mixture of salts. J. Dairy Sci. 97(8): 4733-4744.

Rodrigues, J. F., V. R. Souza, R. R. Lima, J. D. S. Carneiro, C. A. Nunes and A. C. M. Pinheiro. 2016. Temporal dominance of sensations (TDS) panel behavior: A preliminary study with chocolate. Food Qual. Prefer. 54: 51-57.
Romani, S., G. Sacchetti, P. Pittia, G. G. Pinnavaia and R. M. Dalla 2002. Physical, chemical, textural and sensorial changes of portioned Parmigiano Reggiano cheese packed under different conditions. Food Sci. Technol. Int. 8(4): 203-211.

Saint-Eve, A., M. Panouillé, C. Capitaine, I. Déléris and I. Souchon. 2015. Dynamic aspects of texture perception during cheese consumption and relationship with bolus properties. Food Hydrocoll. 46: 144-152.

Sforza, S., V. Cavatorta, F. Lambertini, G. Galaverna, A. Dossena and R. Marchelli. 2012. Cheese peptidomics: A detailed study on the evolution of the oligopeptide fraction in Parmigiano-Reggiano cheese from curd to 24 months of aging. J. Dairy Sci. 95(7): 3514-3526.

SIAP. 2017. Boletín de Leche abril-junio de 2017. Secretaria de Agricultura, Ganadería, Desarrollo Rural, Pesca y Alimentación, México. Available from: https://www.gob.mx/siap/documentos/ boletin-de-leche?state=draft. [Last accessed on 2017 Sep 03].

Stone, H. and J. L. Sidel. 2004. Measurement. In: Stone H, Sidel JL, (Eds.), Sensory Evaluation Practices. $3^{\text {rd }}$ ed. Elsevier, Academic Press, San Diego, CA.

Teubner, C., H. Mair-Waldburg and F. W. Ehlert. 2009. El Gran Libro del Queso: La Cocina Práctica del Queso y una Completa Enciclopedia Ilustrada con Fotografías en Color. Círculo de Lectores. España, Everest.

Villegas, G. A., M. A. Santos and M. A. Hernández. 2009. Los quesos mexicanos genuinos: contribución a su rescate a través de la vinculación universidad-productores. Rev. Claridades Agropecu. 191: 29-35.

Witt, T. and J. R. Stokes. 2015. Physics of food structure breakdown and bolus formation during oral processing of hard and soft solids. Curr. Opin. Food Sci. 3: 110-117.

XLSTAT. 2017. Data Analysis and Statistical Solution for Microsoft Excel. Addinsoft, Paris. 